\title{
Biology of the introduced copepod Pseudodiaptomus inopinus in a northeast Pacific estuary
}

\author{
Jeffery R. Cordell ${ }^{1, *}$, Mikelle Rasmussen ${ }^{2}$, Stephen M. Bollens ${ }^{3}$ \\ ${ }^{1}$ University of Washington, School of Aquatic and Fishery Sciences, Box 355020, Seattle, Washington 98195-5020, USA \\ ${ }^{2}$ University of Washington, School of Oceanography, Box 357940, Seattle, Washington 98195-7940, USA \\ ${ }^{3}$ Washington State University Vancouver, School of Earth and Environmental Sciences \& School of Biological Sciences, \\ 14204 NE Salmon Creek Avenue, Vancouver, Washington 98686-9788, USA
}

\begin{abstract}
Compared to other regions, estuaries and coastal bays along the west coast of North America have experienced the largest number of invasions by nonindigenous planktonic copepods. Eight species of copepods from Asia, including 2 species of the genus Pseudodiaptomus, have been reported in coastal bays of northern California, and a third species of Asian Pseudodiaptomus ( $P$. inopinus) has become established in the Columbia River estuary and many smaller estuaries in the northeast Pacific Ocean. It can dominate the plankton in fresh and oligohaline tidal waters of estuaries that are utilized as rearing grounds for a variety of larger invertebrates and fishes. In July 1998 we initiated a 16 mo study of $P$. inopinus in the Chehalis River estuary, Washington State, USA, to document its biology, ecological relationships with other holoplankton, and importance as prey for fish and invertebrate planktivores. In 1998 P. inopinus reached peak densities in the late summer/early autumn period of low river flow but a similar peak was not seen in the same period in 1999, when densities of the copepod were significantly lower. These interannual density differences did not appear to be caused by between-year differences in predation or river flooding, but could have resulted from cooler temperatures and higher river flows that occurred in the Chehalis River in 1999. Other abundant planktonic copepods were separated from $P$. inopinus either temporally (Eurytemora affinis) or spatially (Acartia spp., Eurytemora americana) within the estuary, over a relatively short segment of the estuary spanning salinities of 0 to $10 \mathrm{psu}$. This separation may imply that $P$. inopinus experienced little competition when it was introduced; alternatively, it may have altered the distribution of other copepods in the estuary. $P$. inopinus was rare in the diets of estuarine fishes, but comprised an important and sometimes dominant prey for mysid shrimp Neomysis mercedis and juvenile caridean shrimp Crangon franciscorum. In turn, N. mercedis was an important prey item for estuarine fishes, and thus the main impact of $P$. inopinus on the estuarine food web was via this pathway.
\end{abstract}

KEY WORDS: Estuary · Northeast Pacific · Copepoda · Pseudodiaptomus · Invasive species · Planktivores

\section{INTRODUCTION}

It has been well demonstrated that invasions by introduced species in terrestrial and marine benthic ecosystems have caused profound economic and environmental damage. While such severe impacts have been less often reported for planktonic invaders, in several cases ecological changes caused by introduced plankton have been shown or hypothesized to be large. In the Black and Azov Seas, invasion by the northwestern Atlantic ctenophore Mnemiopsis leidyi coincided with huge decreases in commercially important fishes, presumably contributing to their decline through predation and competition (Shiganova \& Bulganova 2000, Kideys 2002, Bilio \& Niermann 2004). This invasion was accompanied by other ecological 
changes, including shifts in chlorophyll patterns and concentrations. In a number of large North American lakes and reservoirs, recent invasions by at least 3 species of non-native cladocerans have occurred (Dzialowski et al. 2000, MacIsaac et al. 2000, Therriault et al. 2002). Two of them, the predators Bythotrephes longimanus and Cercopagis pengoi, appear to have negatively affected native planktonic species and their fish predators (Yan \& Pawson 1997, Benoit et al. 2002, Boudreau \& Yan 2003).

The largest number of documented invasions by planktonic marine/estuarine species have occurred in estuaries on the west coast of North America. The most striking example of this is in the Sacramento-San Joaquin estuary (including San Francisco Bay), which has seen the introduction of the Asian planktonic calanoid copepods Pseudodiaptomus marinus, P. forbesi, Sinocalanus doerrii, Acartiella sinensis and Tortanus dextrilobatus, and the cyclopoids Limnoithona sinensis, L. tetraspina, and Oithona davisae. The copepod fauna there is now primarily East Asian in some parts of the bay (Orsi \& Ohtsuka 1999, S. M. Bollens \& J. R. Cordell unpubl.). One species, T. dextrilobatus, appears to have the capacity to severely impact the remaining native copepods in San Francisco Bay through predation (Hooff \& Bollens 2004). At least 3 of the introduced copepod species established in San Francisco Bay have also recently been introduced to the Columbia River estuary, L. tetraspina, P. forbesi and $S$. doerrii, and the latter 2 have become abundant there. They were apparently introduced to the Columbia River either from San Francisco Bay or by transoceanic transport (Sytsma et al. 2004). In the Columbia River and a number of other estuaries in Washington and Oregon, a different Asian copepod not found in San Francisco Bay, Pseudodiaptomus inopinus, has become a dominant planktonic tidal brackish-oligohaline species (Cordell et al. 1992, Cordell \& Morrison 1996, Bollens et al. 2002). Despite the extensive nature of these invasions in both regional distribution and post-invasion densities, little is known of the biology or ecological effects of these copepods in their invaded habitats.

In this study we examine the biology and ecology of a population of Pseudodiaptomus inopinus that has invaded the Chehalis River estuary, Washington. This copepod was first recorded there in 1992 (Cordell \& Morrison 1996), where it remained extremely abundant at least until summer 2004 (J. R. Cordell unpubl. data). There have been few studies of the biology of $P$. inopinus in Asia, and none in invaded systems, so the main goal of this work was to provide basic biological and ecological information about this species. The questions addressed in this study were: (1) what are the overall patterns of seasonal abundance of $P$. inopinus in the Chehalis River estuary, how do they relate to river conditions, and how do they compare to those found in its native range; (2) what are the distribution patterns of $P$. inopinus within the estuary in relation to season and river conditions; and (3) does $P$. inopinus enter the estuary's food web as a prey resource for fish and invertebrate predators?

\section{MATERIALS AND METHODS}

The Chehalis River is located in southwestern Washington, USA, where it enters a coastal embayment, Gray's Harbor (Fig. 1). We sampled invertebrates and measured salinity and temperature twice-monthly at 3 salinity-based stations likely to span the highest densities of Pseudodiaptomus inopinus, determined from earlier studies (Cordell \& Morrison 1996). These stations were located at bottom salinities of $\sim 1,3$, and $6 \mathrm{psu}$, and occurred at different locations in the estuary on different dates, depending on seasonal conditions (Fig. 2). We began sampling on 10 July 1998 and ended on 3 November 1999. Stations were located using a YSI portable salinity-temperature meter; beginning on 21 August 1998, station coordinates were recorded using a hand-held global positioning system unit. Sampling occurred within $1 \mathrm{~h}$ of flood slack tide. River flow data from the Chehalis River at Porter, Washington, USA, which is located ca. 25 river $\mathrm{km}$ upstream of the study site, were obtained from the United States Geo-

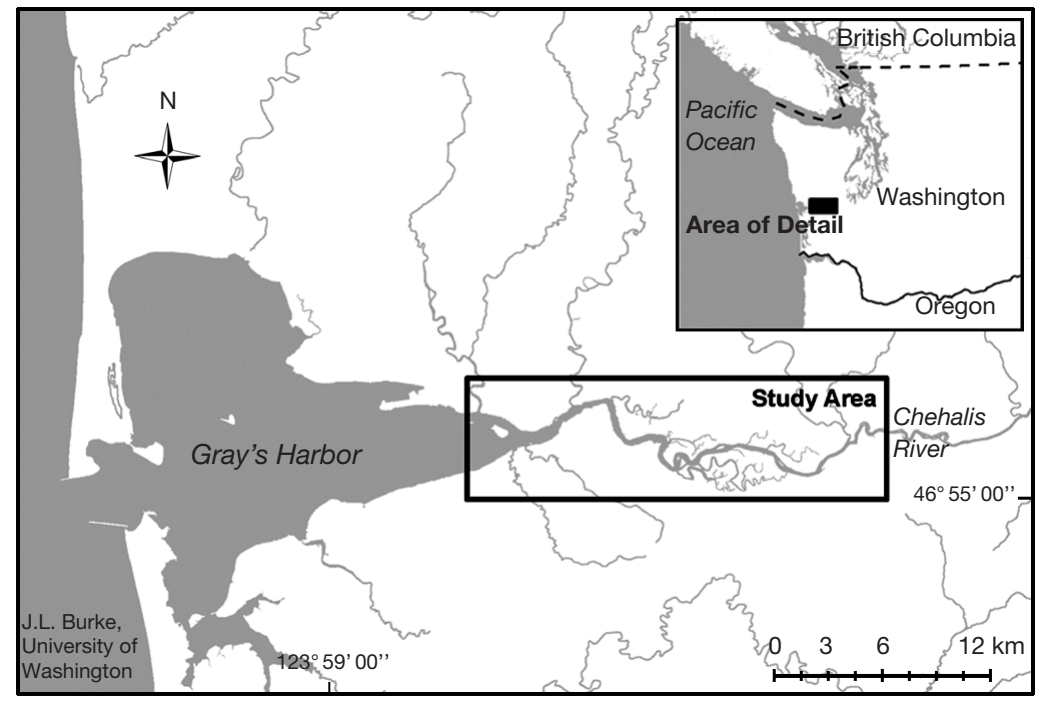

Fig. 1. Location of Chehalis River estuary, Washington, USA, and study area 

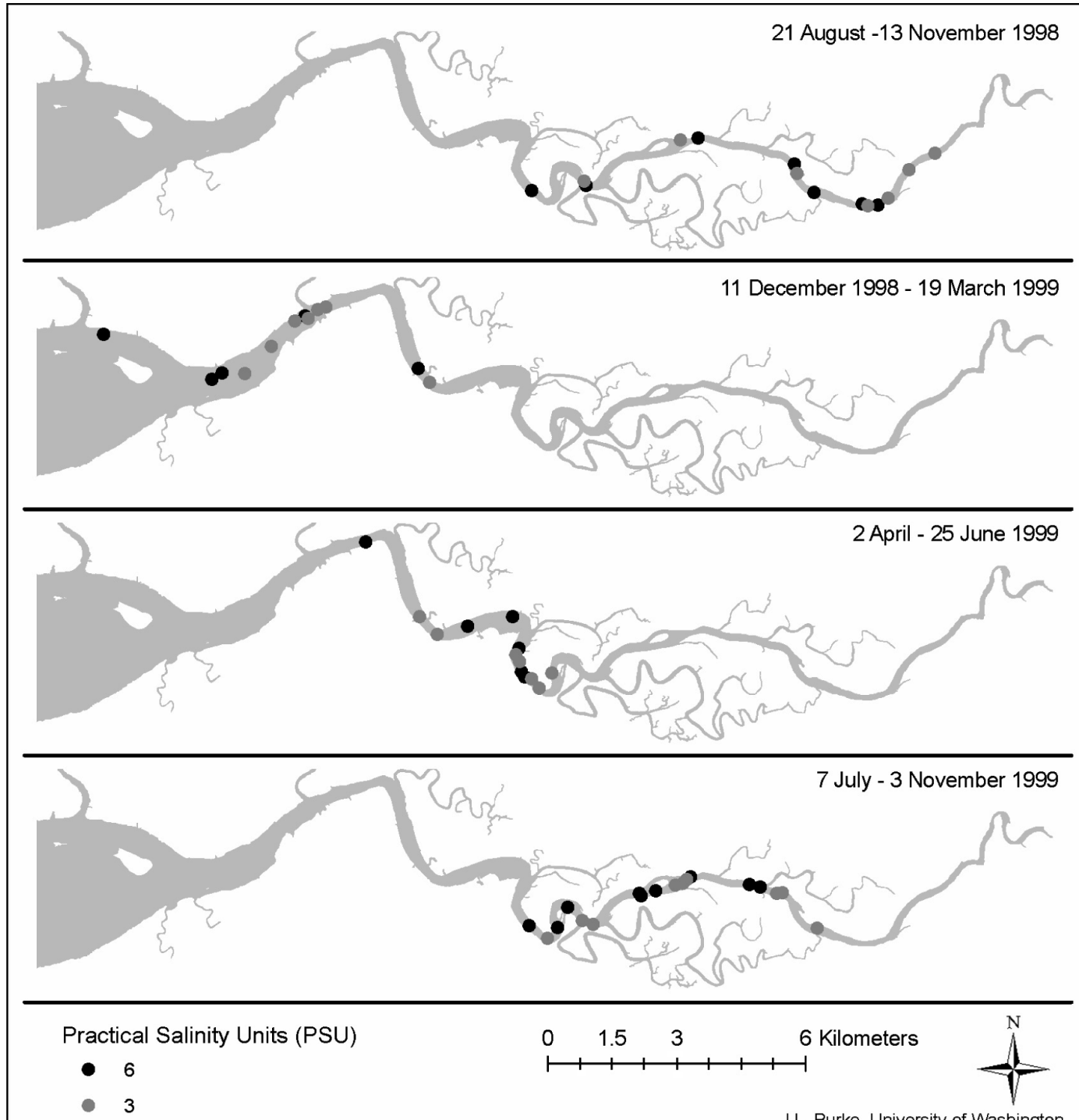

7 July - 3 November 1999

Fig. 2. Location of 3 and 6 psu sampling stations in Chehalis River estuary in 4 seasons during 1998 and 1999. Station coordinates for Figs. $2 \& 3$ are available from the corresponding author

logical Survey National Water Information System (http://waterdata.usgs.gov/nwis/).

At each station, 3 replicate vertical plankton tows were taken from a small $(5 \mathrm{~m})$ boat, using a plankton net of $0.5 \mathrm{~m}$ diameter and $0.073 \mathrm{~mm}$ mesh. The net was lowered to the bottom, depth was recorded, and the vertical orientation of the line was maintained by maneuvering the boat. After ca. $30 \mathrm{~s}$ the net was pulled to the surface at a speed of ca. $0.5 \mathrm{~m} \mathrm{~s}^{-1}$. Additional stations were sampled on 17 October $1998(\mathrm{n}=10)$ and 6 August and 3 November $1999(\mathrm{n}=8)$ to document the upstream and downstream distribution of Pseudodiaptomus inopinus and other abundant copepods in the Chehalis River estuary during periods of low river flow and high $P$. inopinus densities. The additional stations were distributed between 0 to $22.9 \mathrm{psu}$ at ca. 3 psu intervals, from several $\mathrm{km}$ below the mouth of the river in Gray's Harbor to ca. river km 24 (Fig. 3). Samples were fixed in $10 \%$ buffered formalin solution.

To obtain larger epibenthic invertebrate predators, we sampled qualitatively with a $38 \times 17 \mathrm{~cm}$ mouth opening epibenthic sled sampler with $0.6 \mathrm{~mm}$ mesh on each zooplankton sampling date at each of the 3 regularly sampled salinity-based stations. The sled was lowered to the bottom and towed slowly for about $5 \mathrm{~min}$, paying out line as needed to keep it on the bottom. If few or no invertebrates were obtained, one additional sample was attempted. Invertebrates were fixed as for 


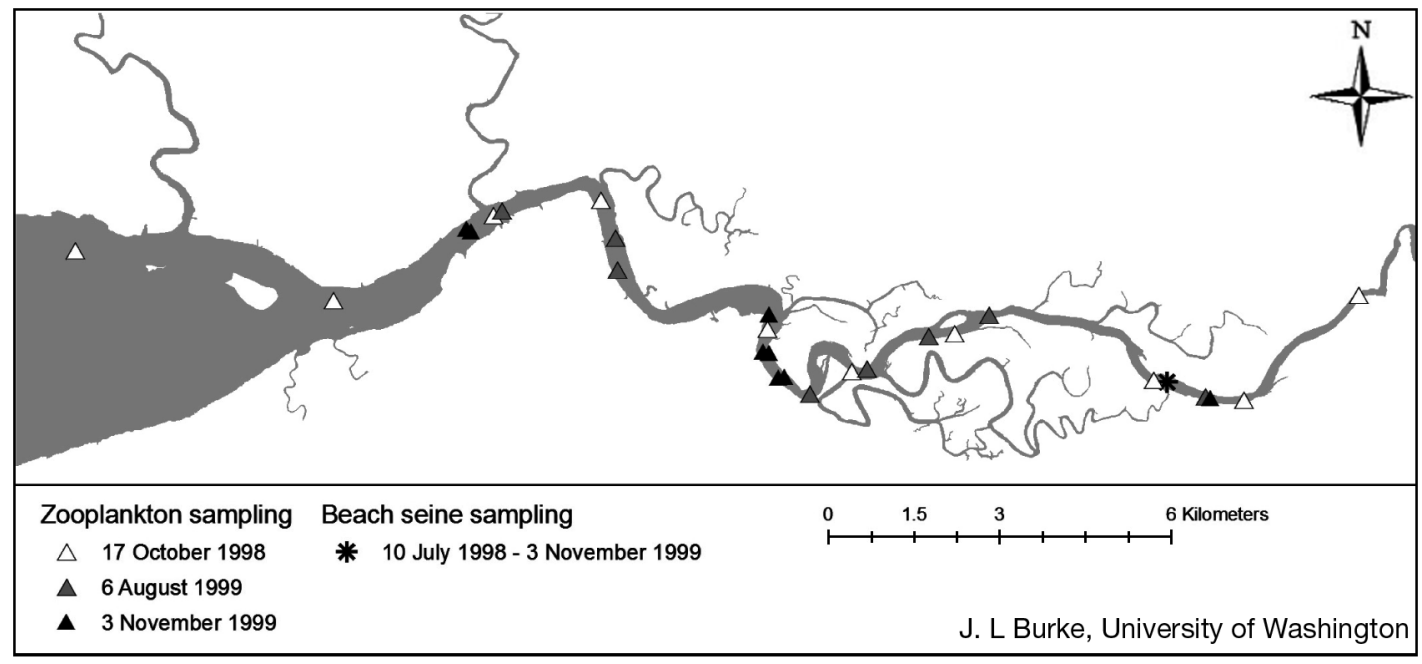

Fig. 3. Extended salinity zooplankton stations and beach seine sampling location

the zooplankton. For one predator, the mysid Neomysis mercedis, the full range of life-history stages was collected by the sled, and in the laboratory up to 25 adults and 20 juveniles were measured (from tip of telson to anterior margin of carapace) and the adults were sexed.

Fish were collected for gut content analysis on each sampling date, at 1 station located in the brackisholigohaline region ( 0 to 6 psu bottom salinity) of the estuary at river $\mathrm{km} 21$ (Fig. 3). Samples were taken with a $37 \mathrm{~m}$ floating beach seine consisting of two $18 \mathrm{~m}$ panels made of $3 \mathrm{~cm}$ mesh with a $2 \times 2.4 \times 2.3 \mathrm{~m}$ bag made of $6 \mathrm{~mm}$ mesh. The net was deployed with a small boat, parallel to shore in water deeper than $2 \mathrm{~m}$, and slowly retrieved to shore. For each fish species caught, up to 10 individuals from each $10 \mathrm{~mm}$ size class were retained. Retained fish were killed in a solution of ms-222 (tricaine) before fixation. Additional beach seine sampling was conducted on 15 and 30 April, 14 and 28 May, 11 June, 9 July, 5 August, and 3 September 1999 at up to 5 additional stations both up- and downstream from the regular fish sampling station. The purpose of this more extensive sampling was to obtain additional information about the feeding of commercially and culturally important juvenile salmon on introduced vs. native copepods during the time in which salmon outmigrated through the estuary. Fish were preserved as for zooplankton.

In the laboratory, plankton samples were quantitatively subsampled, if necessary, using a Hensen's Stempel pipette to obtain ca. 200 of the most abundant copepod taxon. Plankton taxa were enumerated and all adult copepods were identified to species. Life history stages of abundant taxa were also designated: for Pseudodiaptomus inopinus, nauplii and copepodid stages were identified (i.e. nauplius, copepodite I-V, adult male, adult female, gravid female); other copepods were identified to more general life history stage (i.e. copepodid, adult male, adult female, gravid female). We also separated 2 distinct morphotypes of male $P$. inopinus based on the shape of the left side of their fifth legs: in one type this appendage is paddle-shaped and in the other it is thumb-shaped (Fig. 4).

For known or hypothesized planktivorous fishes, up to 10 individuals (if available) of each species from each sample date/station were analyzed for gut contents. Each individual was weighed (damp weight) to the nearest $0.01 \mathrm{~g}$, and length was measured (fork length for juvenile salmon, total length for others). The stomach was excised and contents were removed and

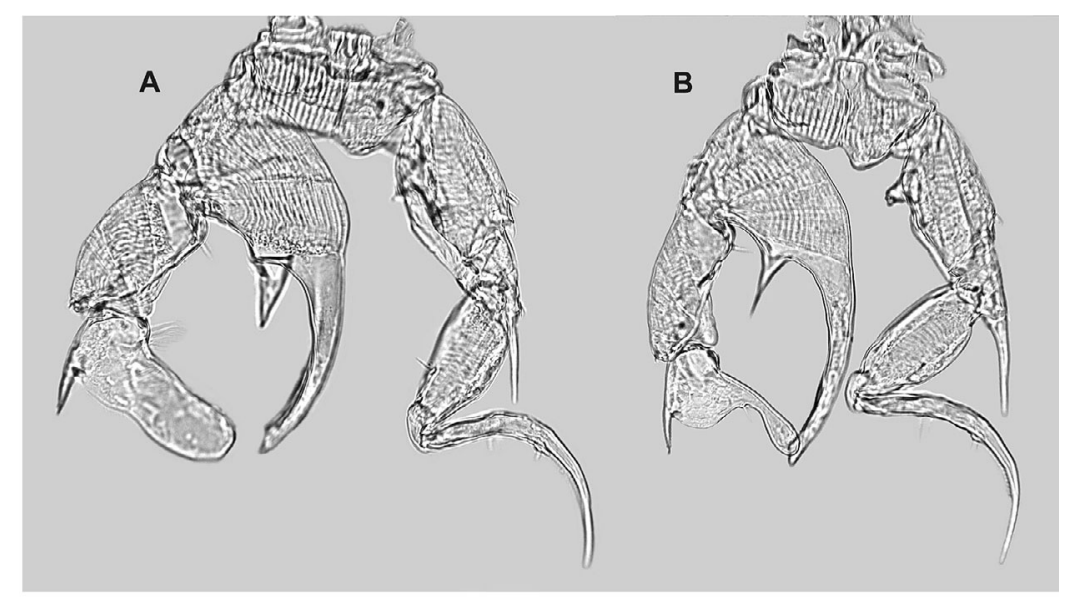

Fig. 4. Pseudodiaptomus inopinus. Photomicrographs of fifth legs of 2 morphotypes of male. A: paddle-shaped; B: thumb-shaped 
weighed in their entirety. Prey taxa were separated into categories as specific as digestion would allow and each prey category was enumerated and weighed to the nearest $0.0001 \mathrm{~g}$. Diet contents of 2 abundant invertebrate predators, Neomysis mercedis and juveniles of the caridean shrimp Crangon franciscorum, were also analyzed. Up to 20 adult and 20 juvenile individuals were sexed (male, female, gravid female) and measured for total length (tip of rostrum to end of telson). Stomachs were removed using fine needles (mounted insect pins) and each stomach was teased open in a drop of water on a plastic petri dish. Prey were enumerated at $60 \times$ magnification with a dissecting microscope, by counting them using one diagnostic characteristic for each prey type, e.g. caudal rami or fifth legs for copepods, dactyls of second gnathopod for amphipods.

To compare river temperatures and densities of Pseudodiaptomus inopinus life history stages between the 2 sampling years, we log-transformed the data and conducted 3-way ANOVAs with station, year, and month as factors, and all 2-way interactions, using SPSS version 11.5. These analyses were only performed on data from July to November as these months were sampled in both years.

\section{RESULTS}

\section{River hydrography}

In both years, highest mean river temperatures corresponded with late summer/early autumn periods of low flow (Figs. $5 \&$ 6). With the onset of late autumn and winter floods, temperatures dropped and remained relatively low throughout the January to April period of high river flows. River flow was significantly higher in 1999 than in 1998 (paired $t$-test, $\mathrm{p}=0.011$ ) (Fig. 5). Mean temperatures ranged from a high of $20.9^{\circ} \mathrm{C} \pm 0.1$ (SD) on 7 August 1998 to a low of $6.4^{\circ} \mathrm{C} \pm$ 0.2 on 19 February 1999. During the low flow period from early July to mid-October mean river temperature was ca. $2^{\circ} \mathrm{C}$ warmer in $1998\left(19.1^{\circ} \mathrm{C} \pm 1.7\right)$ than in 1999 $\left(17.4^{\circ} \mathrm{C} \pm 1.6\right)$ at all 3 sampling stations (Fig. 6), and this difference was statistically significant (3-way ANOVA, $p=0.005$ ). The location of the 3 and 6 psu sampling stations varied among seasons: in summer and autumn 1998, these stations occurred from river $\mathrm{km} 12$ to 23, in winter 1998-99 from river $\mathrm{km} 0$ to 8 , in spring 1999 from river km 5 to 13, and in summer and autumn 1999 from river $\mathrm{km} 12$ to 20 (Fig. 2).

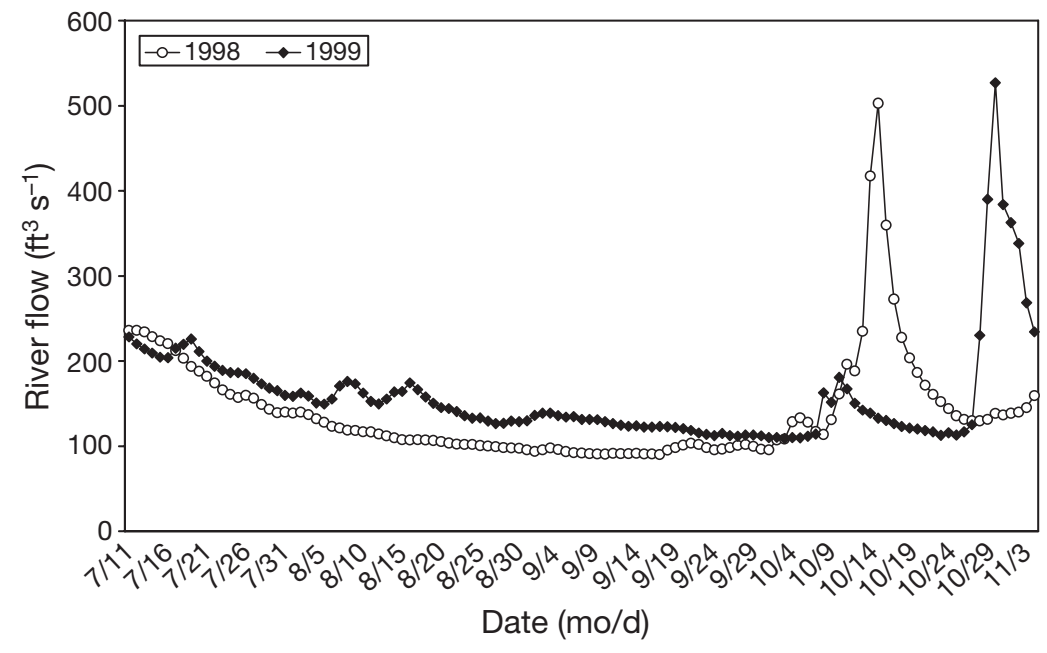

both years, measured at Porter, Washington. $1 \mathrm{ft}^{3}=0.0283 \mathrm{~m}^{3}$ 


\section{Copepod abundance and distribution}

Total Pseudodiaptomus inopinus densities increased rapidly between the first sampling date on 10 July 1998 and peak densities (exceeding 10000 ind. $\mathrm{m}^{-3}$ ) that occurred from late August through mid-September 1998 (Fig. 7). After this, densities quickly declined to $<1000$ ind $\mathrm{m}^{-3}$, and stayed low until increasing in January 1999. Densities were quite variable in 1999, reaching peaks in April and May. Unlike 1998, total densities in 1999 never approached 10000 ind. $\mathrm{m}^{-3}$ and there was no large abundance peak in late summer/ early autumn. Grouped by month, densities of each life history stage (female and male adults, copepodids, nauplii) were greater in 1998 than in 1999 July to September (Fig. 8). These between-year density differences were statistically significant for each life history stage (3-way ANOVA, $\mathrm{p}<0.0003$ ). In 1998, nauplii and copepodid stages dominated the $P$. inopinus population from July to October, including during peak den-
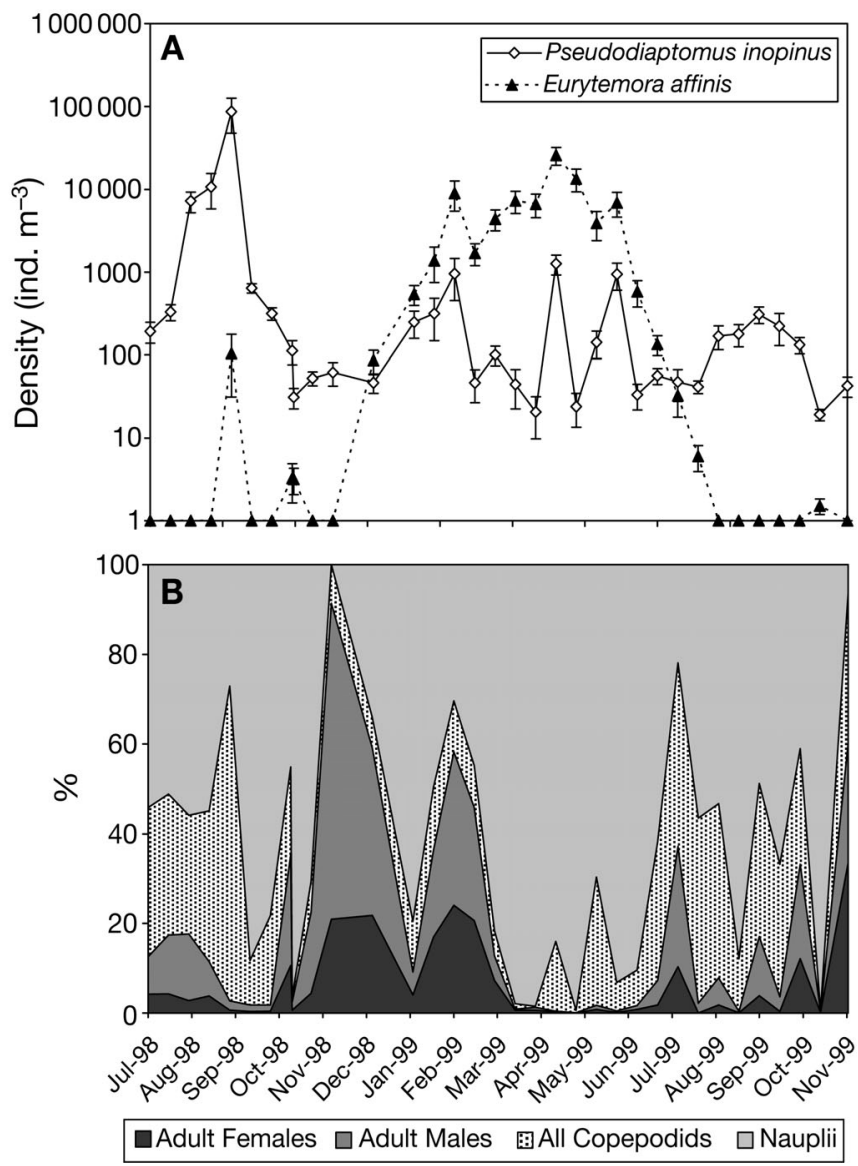

Fig. 7. Eurytemora affinis and Pseudodiaptomus inopinus. Total density (mean \pm SE) (A) and (B) life-history stage percent composition of $P$. inopinus from all stations combined $(\mathrm{N}=9)$ in Chehalis River estuary 10 July 1998 to

3 November 1999. \%: Percent composition by numbers sity periods, whereas adults dominated from late October through mid-December. In 1999, nauplii and copepodids were the dominant stages throughout the year, except on the last sampling date in November, when densities were very low. Total densities of the calanoid copepod Eurytemora affinis were very low during periods of peak $P$. inopinus density in 1998. Densities of $E$. affinis increased in December-January to densities $>1000 \mathrm{~m}^{-3}$ that persisted from late January-late May 1999. After this, densities decreased rapidly and $E$. affinis was nearly absent from the samples from August-November 1999.

Gravid female Pseudodiaptomus inopinus were present throughout the study period, except on the 23 July 1999 sampling date, when no females were found (Fig. 9A). Both gravid and non-gravid females were most abundant in late summer 1998 and again in winter 1999. Gravid females comprised $>50 \%$ of the female numbers on several sampling dates in late summer/early autumn 1998 but dropped to $<25 \%$ from late autumn through December 1998 (Fig. 9C). In 1999 they comprised $>50 \%$ of total females on most sampling dates from late February through May 1999 and then dropped to much lower percentages from June to September before increasing in proportion again in October 1999. Male $P$. inopinus of both fifth leg morphotypes had peak densities similar to those for females in late summer 1998 and winter 1999 (Fig. 9B). On these and most other sampling dates the thumbshaped type was more abundant than the paddleshaped type. Relative composition of the paddleshaped type was similar to that for gravid females, comprising larger percentages of total males only in late winter/early spring, when copepod densities were very low (Fig. 9D). Other than during this period, the thumb-shaped morphotype usually comprised higher percentages of the male numbers.

During peak abundances in 1998, Pseudodiaptomus inopinus was most abundant at Station 3 ( 0 psu) on 2 of the 3 sampling dates, with densities approaching or exceeding 100000 ind. $\mathrm{m}^{-3}$ (Fig. 10C). There were several other, lower peaks in densities of $>1000$ ind. $\mathrm{m}^{-3}$ that occurred in late winter 1998-1999 at Stations 1 \& 2 (Fig. 8A,B) but not at Station 3, where P. inopinus either did not occur or had densities $<10$ ind. $\mathrm{m}^{-3}$ from mid-November through early March. Life history stage composition at each sampling station (Fig. 10D-F) was similar to that for the combined data (Fig. 7B), with larger proportions of adults in winter and more nauplii and copepodids at other times. Station $3(0 \mathrm{psu})$ tended to have lower proportions of adults and higher proportions of nauplii and copepodids in summer and autumn.

In the October 1998 distributional sampling, Pseudodiaptomus inopinus extended $\sim 25 \mathrm{~km}$ upstream in the estuary to 0 psu but did not occur in the most upstream 
Fig. 8. Pseudodiaptomus inopinus. Life history stage densities at 3 sampling stations, comparing 1998 and 1999 for periods sampled in both years
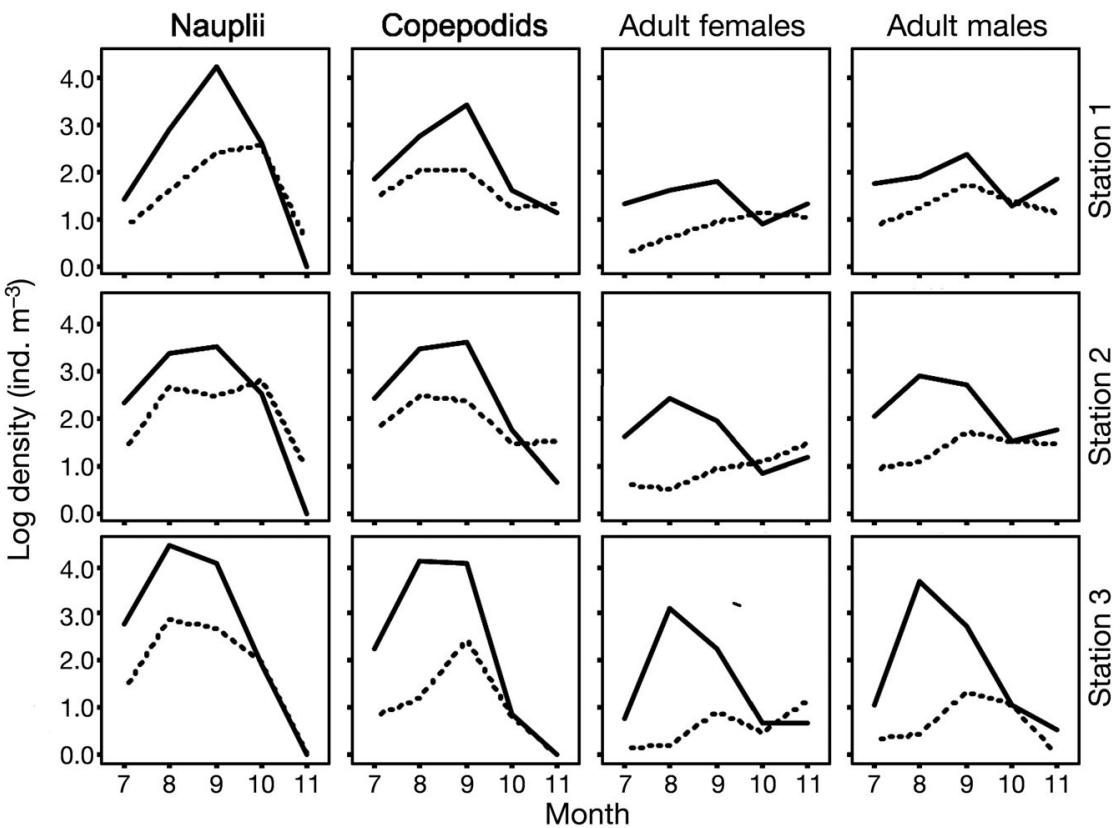

station around river $\mathrm{km} 28$ (Fig. 11). P. inopinus occurred only in samples from a region spanning approximately 10 river $\mathrm{km}$, with highest abundances in a $\sim 4 \mathrm{~km}$ reach encompassing salinities of 0 to $\sim 10$ psu. Similarly, in August and November $1999 P$. inopinus was most abundant at 3 to 10 psu but did not occur at the most upstream stations. Other planktonic copepods were relatively rare in the estuary during the extended distribution sampling periods, except for 2 taxa, Eurytemora americana and Acartia spp., which were abundant at stations with salinities from $\sim 9$ to $21 \mathrm{psu}$, and thus overlapped little with $P$. inopinus in the estuary (Fig. 11).
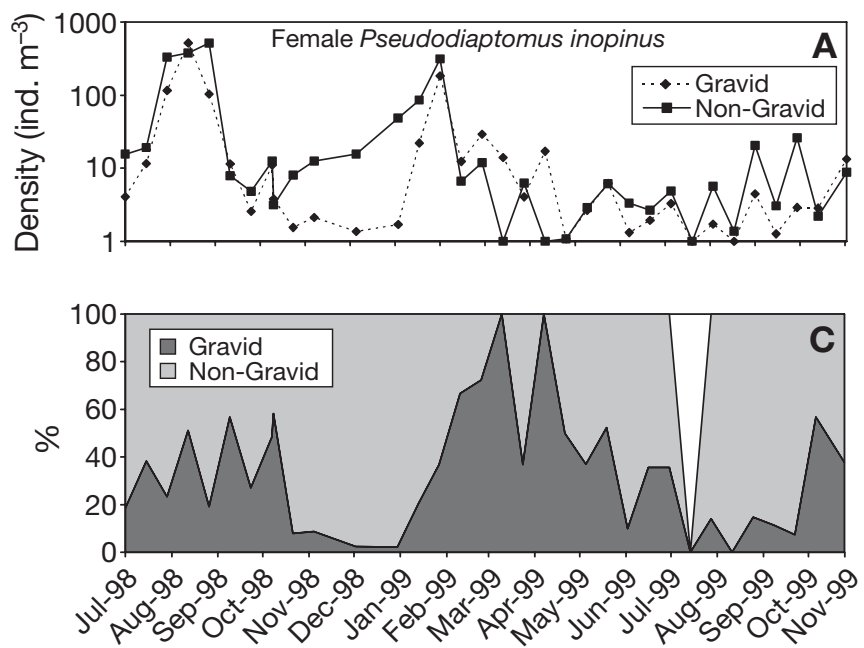

\section{Invertebrate predators}

Adult Neomysis mercedis occurred throughout the year in the epibenthic sled samples ( $N$. mercedis length and life history stage data are available from the corresponding author). Mean lengths were similar ( $\sim 10$ to $11.5 \mathrm{~mm}$ total length) from spring through autumn in both 1998 and 1999. From late January through late May 1999, adults were larger (>12 mm) with largest sizes occurring in February (>15 mm). Juveniles were mostly absent from samples from midAugust through late October in both years. Small juveniles $(<6 \mathrm{~mm})$ occurred in late July 1998 and from mid-
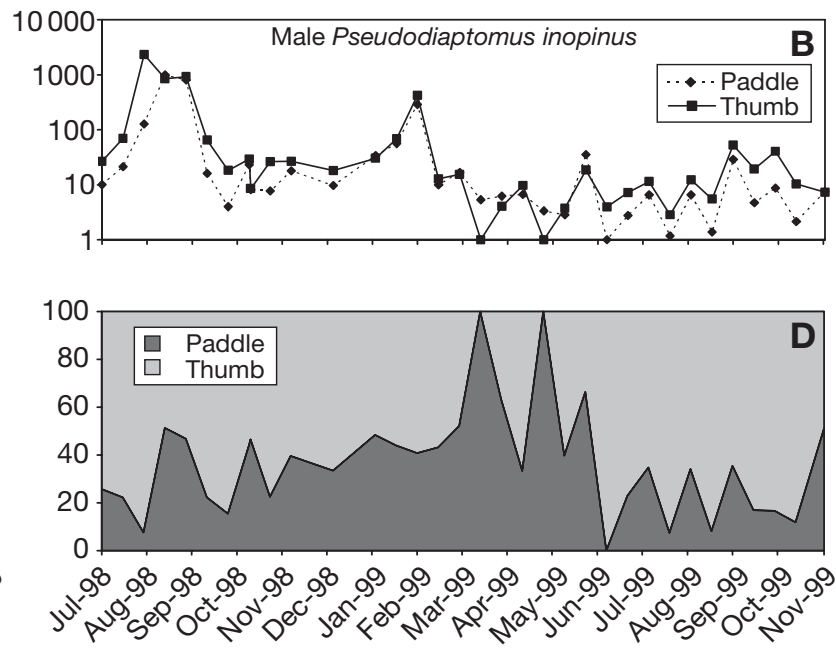

Fig. 9. Pseudodiaptomus inopinus. Total density $(\mathrm{N}=9)(\mathrm{A}, \mathrm{B})$ and percent composition $(\mathrm{C}, \mathrm{D})$ of gravid vs. non-gravid females and 2 fifth-leg morphotypes of males from Chehalis River estuary, Washington, 10 July 1998 to 3 November 1999. \%: Percent composition by numbers 

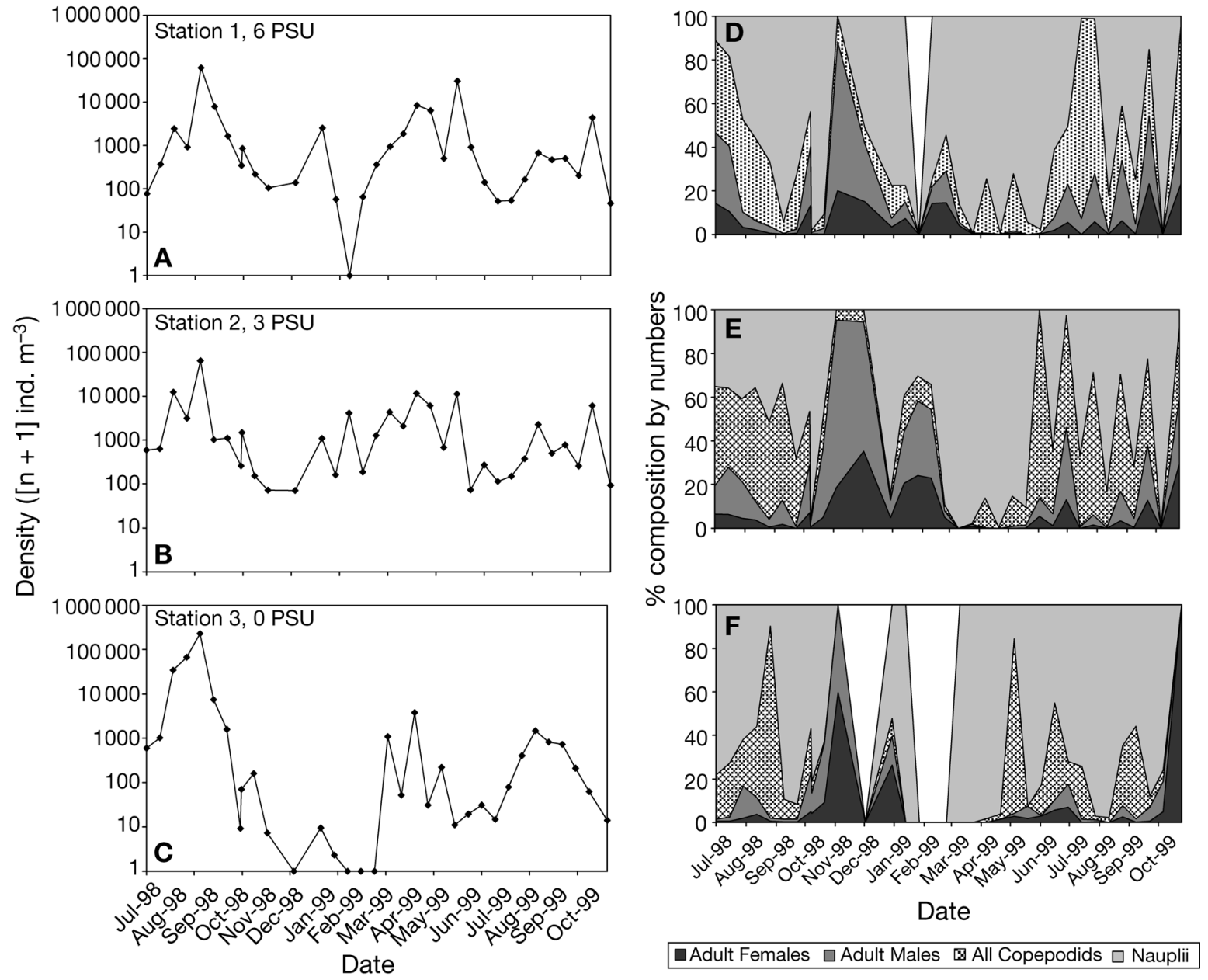

Fig. 10. Pseudodiaptomus inopinus. Total density (A-C) and life-history stage percent composition (D-F) from 3 salinity-based stations in Chehalis River estuary, 10 July 1998 to 3 November 1999

May to late June 1999. Larger juveniles ( 6 to $8.5 \mathrm{~mm}$ ) occurred mostly in the autumn and winter. Females dominated the life history stage composition of N. mercedis on most of the sampling dates. Gravid females dominated on the 7 August and 2 October 1998 sampling dates and from late June to mid-September in 1999. The proportion of gravid females was generally lowest from January through March 1999. Males were scarce from August to October 1998 and then were relatively abundant until mid-September 1999.

Prey occurred in nearly all Neomysis mercedis examined, but in juveniles it was almost always entirely unidentifiable. In adult $N$. mercedis, Pseudodiaptomus inopinus were abundant in diets from 24 July to 30 October 1998, comprising 20 to $80 \%$ of the identifiable prey numbers on each sampling date during that period (Fig. 12). Other relatively abundant prey during this period were harpacticoid copepods (consisting mostly of the species Coullana canadensis, Pseudobradya sp., and Mesochra rapiens) and Coro- phium spp. amphipods. From January to June 1999 $P$. inopinus comprised $<5 \%$ of the diet composition, when mysid diets were dominated by harpacticoid copepods. This was also the only period in which the calanoid copepod Eurytemora affinis occurred in N. mercedis diets. From July to September 1999 Corophium spp. and harpacticoid copepods dominated prey numbers. $P$. inopinus were much less prominent in mysid diets than in the same time period in 1998, except for the 6 August sampling date, on which it comprised $\sim 50 \%$ of prey numbers.

For Crangon franciscorum shrimp, only juveniles were analyzed for diet because few adults were captured and examination of a representative sample of their diets showed little identifiable material and no copepods. The pattern of Pseudodiaptomus inopinus occurrence in the diets of $C$. franciscorum juveniles was similar to that for Neomysis mercedis, with relatively high proportions occurring from 24 July to 30 October 1998 and low proportions in samples taken in 1999 (Fig. 13). Also, as with 


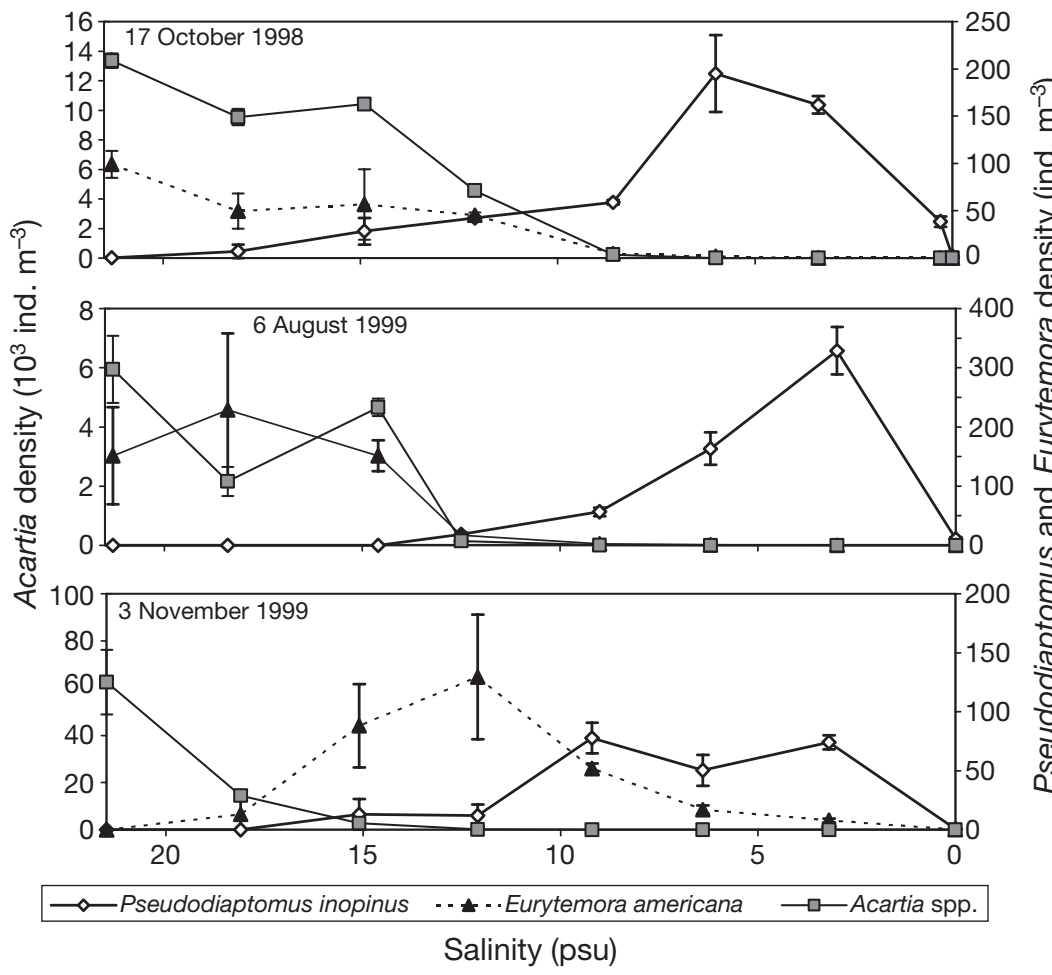

Fig. 11. Pseudodiaptomus inopinus, Eurytemora americana (right axis) and Acartia spp. (left axis). Densities (mean \pm SE) of combined adult and copepodid stages across the salinity gradient in Chehalis River estuary on 3 dates in 1998-1999

\begin{tabular}{ll}
\hline Pseudodiaptomus inopinus & $\square$ Eurytemora affinis \\
$\square$ Harpacticoida & Q Corophium spp. \\
⿴囗大요 Chironomidae & O Other
\end{tabular}

$194040 \quad 3529113540 \quad 45 \quad 8 \quad 24 \quad 20 \quad 3140 \quad 6 \quad 20 \quad 60 \quad 40 \quad 1949 \quad 54 \leftarrow n$

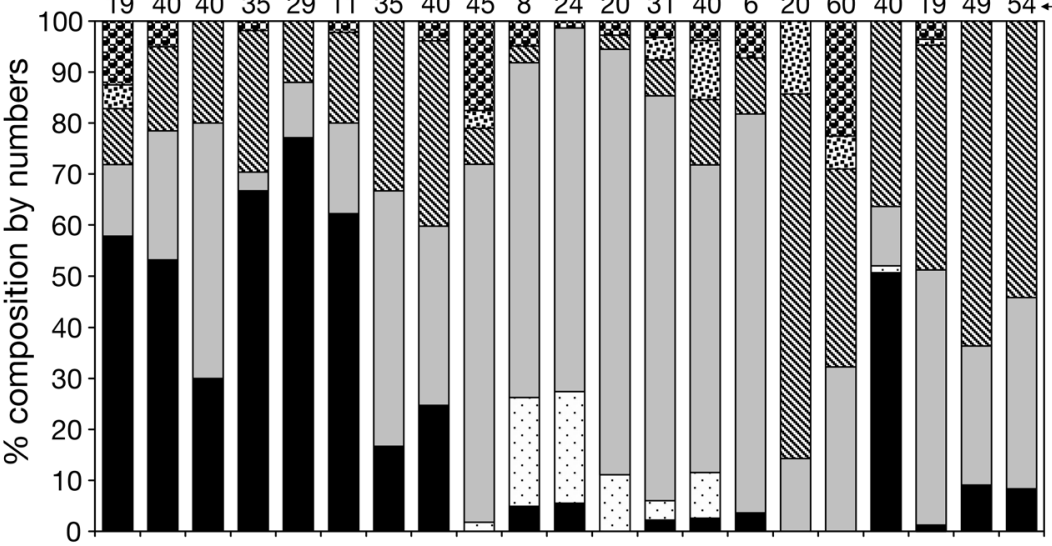

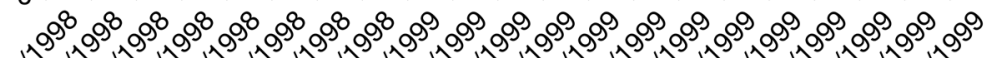

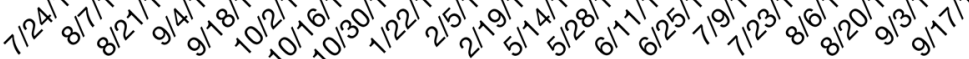

\section{Date $(\mathrm{mo} / \mathrm{d} / \mathrm{yr})$}

Fig. 12. Neomysis mercedis. Percent diet composition by numbers of identifiable prey in $N$. mercedis from Chehalis River estuary 1998-1999; n: number of individual diets examined on each date. Sample dates on which no $N$. mercedis were captured are not included the mysids, there was one instance of relatively high diet composition of $P$. inopinus in 1999 (6 August; $33 \%$ of numerical diet composition). However, there were several differences between Neomysis mercedis and juvenile C. franciscorum diets. Crangon franciscorum fed more on Ostracoda, and $N$. mercedis consumed more Chironomidae (midge) larvae (Figs. 12 \& 13). In 1999 prey numbers were dominated by harpacticoid copepods in juvenile $C$. franciscorum and by Corophium spp. in N. mercedis. Juvenile $C$. franciscorum also consumed $N$. mercedis on several dates.

In both species of invertebrate predators, Pseudodiaptomus inopinus in the diet were dominated by adults on most sampling dates (Fig. 14). Copepodid stages comprised $50 \%$ or more of the $P$. inopinus consumed on 24 September 1998 (both predator species) and 6 August 1999 (Neomysis mercedis). On most dates when both types of predator were sampled, N. mercedis consumed larger proportions of copepodids and adult males and Crangon franciscorum juveniles fed more on adult female $P$. inopinus. Of the adult $P$. inopinus consumed in 1998, males predominated in $N$. mercedis diets. Conversely, C. franciscorum juveniles tended to feed more on female $P$. inopinus. Life history composition of $P$. inopinus in $N$. mercedis diets was more variable in 1999, with mostly females occurring in spring samples and copepodids occurring on only the 6 August and 17 September sampling dates. P. inopinus occurred in the diets of juvenile $C$. franciscorum only on the 6 August sampling date.

\section{Fish predators}

Six species of known or hypothesized planktivorous fishes were relatively abundant in the beach seine samples: juvenile Chinook Oncorhynchus tschawytscha and chum salmon $O$. keta, threespine stickleback Gasterosteus aculeatus, peamouth chub Mylocheilus caurinus, juvenile starry flounder Platichthys stellatus, and American shad Alosa sapidissima. In terms of prey biomass, diets of Chinook salmon, threespine stickleback, and American shad were dominated by the mysid shrimp Neomysis mercedis (Fig. 15). In juvenile 


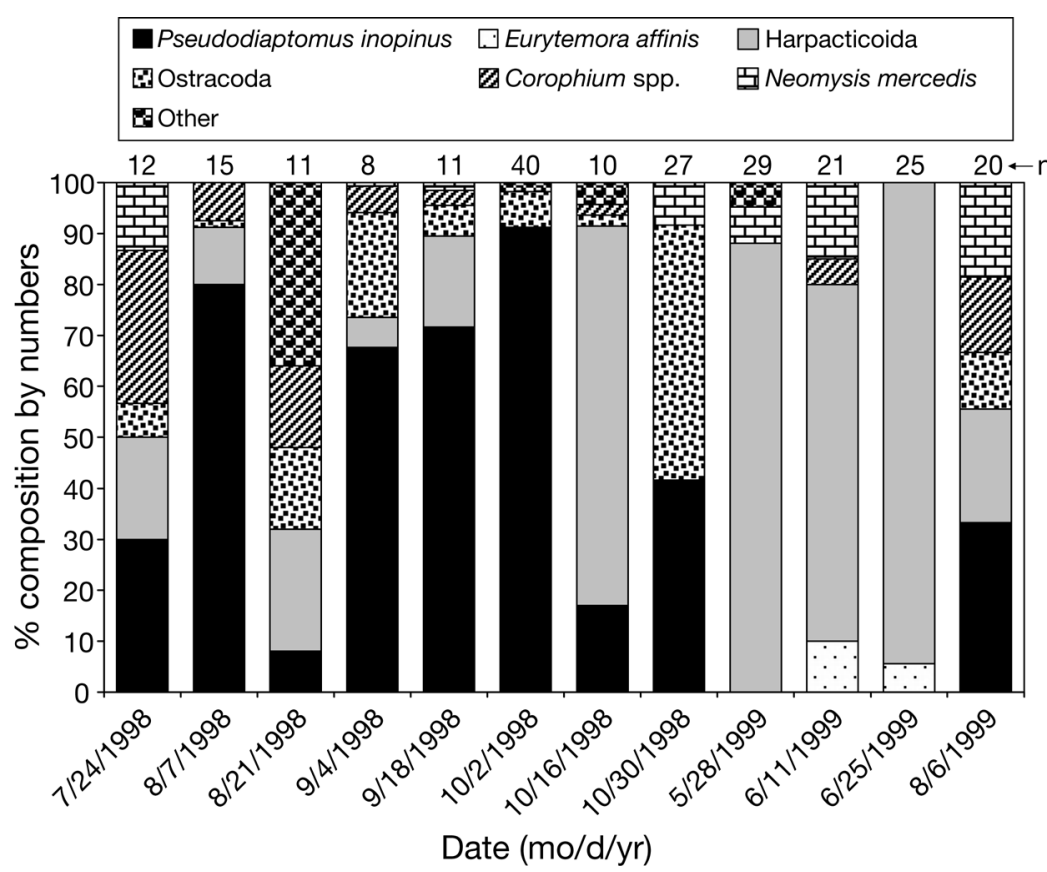

Fig. 13. Crangon franciscorum. Percent diet composition by numbers of identifiable prey in juvenile $C$. franciscorum from Chehalis River estuary 1998-1999; n: number of individual diets examined on each date. Sample dates on which no $C$. franciscorum were captured are not included
$P$. inopinus because the estuary flushing rate was lowest at this time and the copepods could best maintain themselves and proliferate in the brackish-oligohaline region, as they do in their native habitats. However, relatively high abundance in plankton and predator diets occurred only in autumn 1998 and not in autumn 1999. Recruitment of copepodids and nauplii in spring/summer 1999 was not followed by a large increase in adults. This may have been due to predation by the main predators of $P$. inopinus: Crangon franciscorum and Neomysis mercedis. We cannot determine this because we did not measure predator densities, but we note that despite apparently good recruitment of $P$. inopinus juveniles, both of these predators had much lower proportions and total numbers of $P$. inopinus in diets in 1999 than in 1998, possibly indicating a general scarcity of the copepod due to other factors in 1999. We did not encounter any other invertebrate predators, but other fish predators might have been responsible for the decline of $P$. inopinus in 1999. However, most of the planktivorous fishes in the Chehalis River chum salmon and juvenile starry flounder, Chironomidae larvae, pupae, and emergent adults comprised most of the prey weight. Chironomidae and other insects were also relatively abundant in the diets of juvenile Chinook salmon and peamouth chub. The benthic gammarid amphipods Corophium spp. were the most abundant prey taxon in diets of peamouth chub and were also prominent in the diets of juvenile starry flounder.

Pseudodiaptomus inopinus were rare in the fish diets, never comprising more than $1 \%$ of prey biomass (Table 1). The highest numbers of $P$. inopinus occurred in American shad, and were also consumed in small numbers by threespine sticklebacks and juvenile starry flounders (Table 1).

\section{DISCUSSION}

Pseudodiaptomus inopinus is geographically widespread throughout Asia and occurs in a variety of fresh water and estuarine habitats (Mashiko 1951, Shen \& Song 1979, Oka et al. 1991). In Asian estuaries it is part of a plankton assemblage that occurs mainly in fluvialoligohaline reaches at salinities of 0 to $5 \mathrm{psu}$ and is most abundant in autumn (Suh et al. 1991). We hypothesized that the Chehalis River late summer and early autumn low flow period would have peak densities of estuary are found in the lower part of the estuary where $P$. inopinus does not occur, while those that do occur in the brackish-oligohaline region are transitory there (e.g. American shad, smelts) (Simenstad \& Eggers 1981). The decreased numbers in autumn 1999 could not have been due to early flood events in the river, as such events did not occur. Nor could the decrease between 1998 and 1999 have been part of a permanent decline in $P$. inopinus in the Chehalis River estuary because densities exceeding 3000 total adults $\mathrm{m}^{-3}$ have since been found in September 2004 (J. R. Cordell unpubl. data). It is also possible that at the time this study was conducted, $P$. inopinus was a recent invader in the Chehalis River estuary and its population had not yet stabilized. In 1999, temperatures in the Chehalis River were colder by several degrees than in 1998 throughout the late summer and early autumn, and river flows were significantly higher in 1999 than in 1998. While we do not know the biological significance of these factors, or thresholds at which they would affect $P$. inopinus populations, they may have contributed to lowering densities of the copepods in 1999. Little is known of the range of temperatures at which $P$. inopinus occurs in its native habitats, but in at least one Asian estuary where it occurs (Chikugo River, Japan), temperatures are much warmer than in the Chehalis River estuary $\left(22.5\right.$ to $27.8^{\circ} \mathrm{C}$ vs. 6.0 to $20.9^{\circ} \mathrm{C}$ ) (Ueda et al. 2004 and this study). Therefore, it 


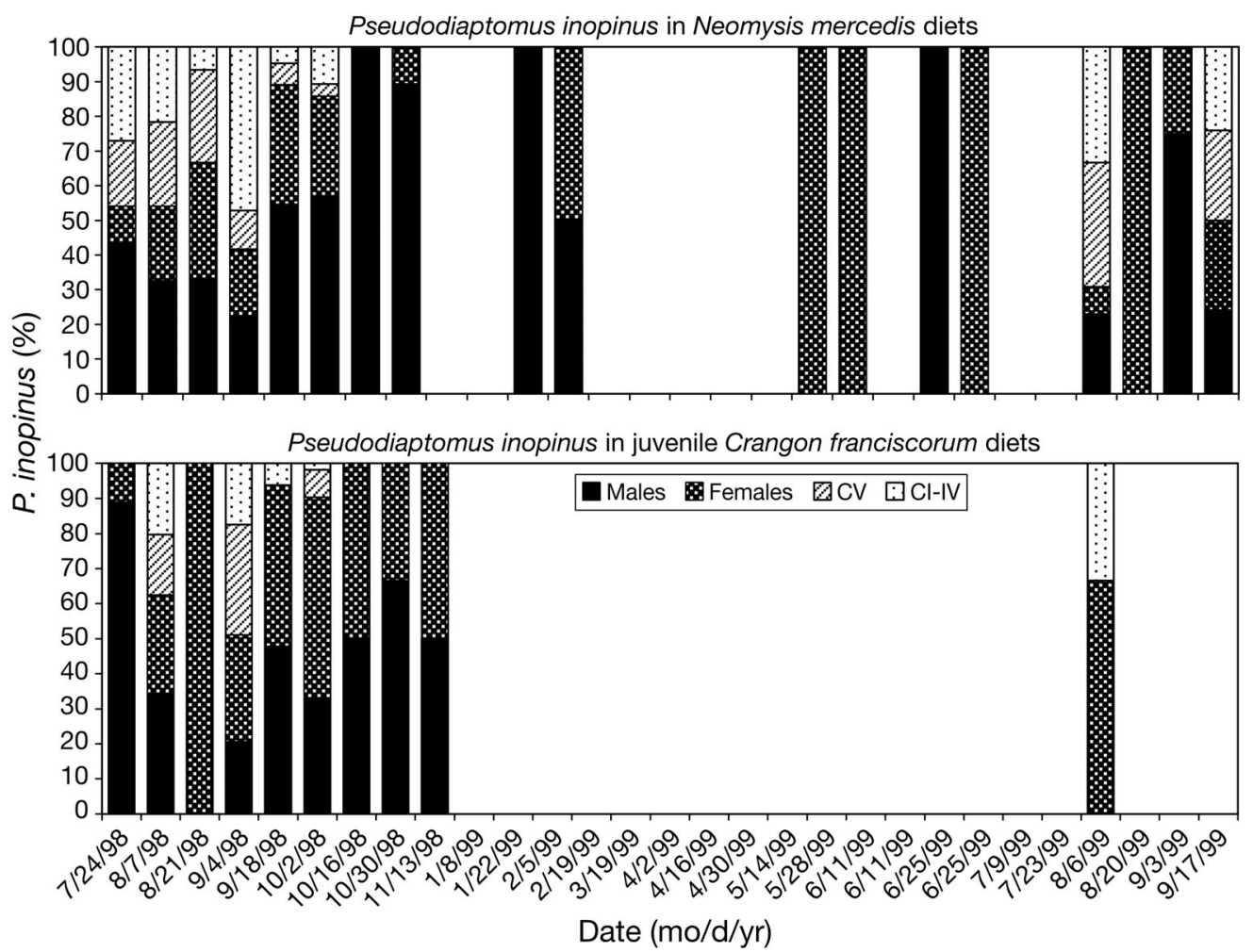

Fig. 14. Percent composition by numbers of life history stages of Pseudodiaptomus inopinus in diets of Neomysis mercedis and juvenile Crangon franciscorum from Chehalis River estuary 1998-1999. No data indicates dates on which no predators were found in samples. \%: Percent composition by numbers; CV: copepod Stage V; CI-IV: copepod Stages I-IV

is possible that $P$. inopinus in the Chehalis River estuary experienced poor recruitment in 1999 because of the cool temperatures that year. Our study was too short to definitively answer these questions and multiple-year sampling of $P$. inopinus in its native and/or

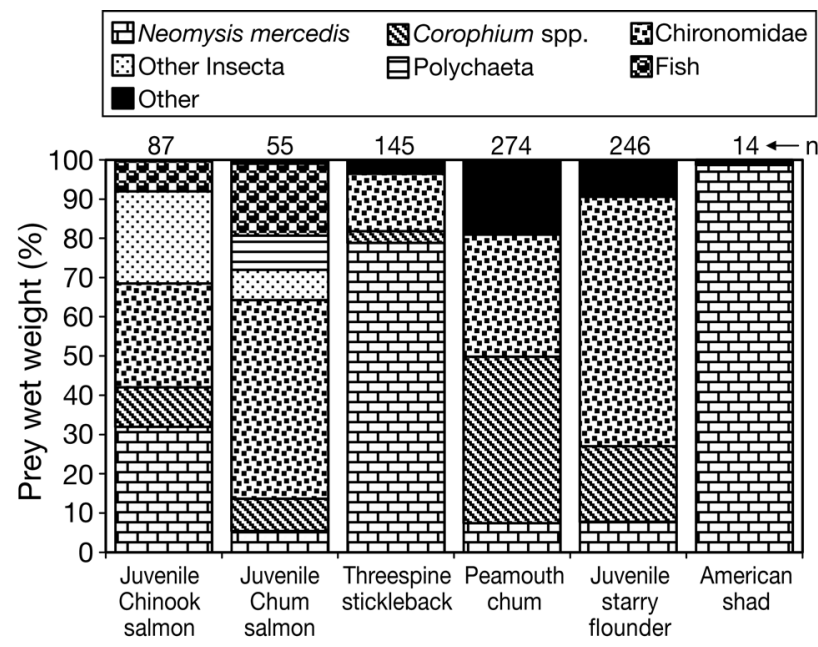

Fig. 15. Overall percent composition by weight of prey from species of potential or known planktivorous fish (beach seinecaptured) from Chehalis River estuary 1998-1999; n: number of individual diets examined for each species invaded habitats would further clarify the degree of and reasons for interannual variation in this species.

Our data show that during flood periods, Pseudodiaptomus inopinus is largely absent from the Chehalis River estuary upstream of the river mouth. In Japan, a recent study by Ueda et al. (2004) concluded that this species repopulates estuaries by residing near the bottom in deep channels in the lower estuary during flood events, and this might also be the mode for repopulating the Chehalis River estuary.

Previous plankton surveys of northeast Pacific estuaries found that Pseudodiaptomus inopinus occurred mainly between salinities of 0 and 12 psu, with highest densities usually occurring around 0 to 6 psu (Cordell \& Morrison 1996, J. R. Cordell unpubl. data). The present study confirms this distribution, and further suggests that it is most abundant in relatively short reaches of Northeast Pacific estuaries (in this study, ca. $4 \mathrm{~km}) . P$. inopinus is a strong vertical migrator, apparently using both light and water movement as cues (Suh et al. 1991, Bollens et al. 2002), so it seems likely that it actively maintains itself in this restricted area within the estuary. It appears to be beneficial for copepods to inhabit brackish-oligohaline regions of estuaries because these regions are often where the estuarine turbidity maximum (ETM) occurs, along with 
Table 1. Pseudodiaptomus inopinus in diets of fish captured in Chehalis River estuary. Fish species: no. of individuals in parentheses. $P$. inopinus: total eaten for each species of fish

\begin{tabular}{|llc|}
\hline Date & Fish species & P. inopinus \\
\hline 10 Jul 98 & American shad (2) & 29 \\
10 Aug 98 & Starry flounder (11) & 2 \\
16 Oct 98 & Starry flounder (19) & 55 \\
21 Oct 98 & Threespine stickleback (10) & 8 \\
30 Oct 98 & Starry flounder (10) & 10 \\
30 Apr 99 & Threespine stickleback (10) & 1 \\
26 Jul 99 & Starry flounder (9) & 5 \\
26 Jul 99 & American shad (4) & 142 \\
5 Aug 99 & Starry flounder (10) & 1 \\
20 Aug 99 & Starry flounder (10) & 8 \\
\hline
\end{tabular}

associated increases in suspended particulate matter, organic carbon, and organic nitrogen. For example, Islam et al. (2005) found that another brackish water copepod, Sinocalanus sinensis, occurred almost exclusively in the ETM region of the Chikugo estuary, Japan, where it appeared to consume elevated levels of organic material via a detritus-based food web. As in our study, these authors found that Acartia and several other copepod species in the estuary did not overlap with the low salinity species. Furthermore, they found that the food source for the copepods appeared to be different in the more saline parts of the estuary, consisting of phytoplankton rather than being detritusbased. Similar food web studies have not been conducted for $P$. inopinus, but it seems reasonable to expect that they also utilize detritus-based food sources in the ETM region of the Chehalis River estuary.

Pseudodiaptomus inopinus may have encountered little competition for resources in its invaded habitats, because there appear to be few native holoplanktonic taxa that co-occur with it in the brackish-oligohaline regions of northeast Pacific estuaries. Two species, the harpacticoid copepod Coullana canadensis and the calanoid copepod Eurytemora affinis, inhabit the ETM regions of US west coast estuaries (Morgan et al. 1997, Kimmerer et al. 1998). However, C. canadensis clearly prefers near-bottom depths and therefore probably does not compete extensively with planktonic copepods (Morgan et al. 1997). In estuaries elsewhere, E. affinis occurs mainly in the spring (Koepcke 2004, Lawrence et al. 2004, David et al. 2005) when P. inopinus would not be abundant. E. affinis formerly occurred throughout the year in the San Francisco estuary (Ambler et al. 1985), but appears to have been adversely affected there by the invasion of Pseudodiaptomus forbesi and the introduced bivalve Potamocorbula amurensis that feeds on E. affinis nauplii but not on $P$. forbesi nauplii (Kimmerer et al. 1994).
Orsi (1995) noted that E. affinis continues to be seasonally present in winter and spring when $P$. forbesi is scarce, both within and upstream of Potamocorbula's range. Similarly, our data show E. affinis was only abundant from January to May. A complicating factor is that E. affinis in the northeast Pacific appears to consist of at least 2 morphologically indistinct species: one is introduced from the Atlantic, occurring in San Francisco Bay and Grays Harbor, Washington, and the other is apparently endemic (Chehalis River estuary and other locations) (Lee 2000, Lee \& Frost 2002). It is unknown whether $P$. inopinus interacts differently with different 'E. affinis' sibling species, or if other abundant introduced filter feeders (e.g. the introduced Asian bivalve Corbicula fluminea in the Columbia River and other estuaries) benefit $P$. inopinus by preying on E. affinis. Clearly this warrants further investigation.

In the Chehalis River estuary, Pseudodiaptomus inopinus appears to have 2 reproductive peaks: one in late summer/early autumn, and the other in late winter/early spring. This is evidenced by peaks of both gravid females and adult males during these times. These results are very similar to those from a 1 yr study of an unidentified Pseudodiaptomus sp. closely related to $P$. inopinus in the Seomjin river estuary, Korea (Park et al. 2005). In our study, gravid female $P$. inopinus comprised the highest female proportions during periods of very low overall population abundance that spanned the end of the high-flow period in late winter/ early spring. This may be evidence of a reproductive strategy in which the copepod repopulates the estuary by means of overwintering adult females that are either previously fertilized or ready for mating.

The presence of 2 very different fifth leg morphotypes of Pseudodiaptomus inopinus has been noted for some time, and the paddle-shaped type has been described as a distinct subspecies (Pseudodiaptomus inopinus saccupodus) (Shen \& Tai 1962). The relative functions of the 2 types of male $P$. inopinus fifth legs are unknown, but may be related to reproduction. In the genus Pseudodiaptomus, the male grasps the female with the right side of the fifth leg and uses the left side to transfer the spermatophore to the female genital area (T. C. Walter pers. comm.). Mating experiments using unfertilized females, and the 2 male morphotypes would help us to understand their role in $P$. inopinus reproduction and potential impact on population dynamics.

Although other introduced Pseudodiaptomus species can be important direct food sources for estuarine fish (e.g. P. forbesi for delta smelt Hypomesus transpacificus in the San Francisco estuary; Nobriga 2002), in the Chehalis River estuary $P$. inopinus was not an important diet component for the fish that we sampled. How- 
ever, it is important prey for Neomysis mercedis and thus fuels higher trophic levels through this invertebrate predator. The diet of at least 3 fishes (Chinook salmon, threespine stickleback, and American shad) was dominated by $N$. mercedis, which also occurred in juvenile Crangon franciscorum diets. N. mercedis is also a principal prey item for $C$. franciscorum in the San Francisco estuary (Siegfried 1982, Wahle 1985). In other estuaries and lakes $N$. mercedis is similarly trophically important, both competing with and providing food for other fish and invertebrate zooplanktivores (Wahle 1985, Chigbu et al. 1998, Feyrer et al. 2003, Hyatt et al. 2005). As a predator, N. mercedis is important in structuring zooplankton assemblages, and in some cases these effects probably exceed those of its fish competitors (Cooper et al. 1992, Chigbu 2004, Hyatt et al. 2005). N. mercedis has the potential for affecting $P$. inopinus populations in estuaries where the 2 species co-occur, but establishing that this is the case will require measuring predation rates and quantifying the population dynamics of $N$. mercedis and $P$. inopinus together. In estuaries, N. mercedis also appears to be an important predator on epibenthic meiofauna, consuming harpacticoid copepods, juvenile gammarid amphipods, and chironomid fly larvae (Johnston \& Lasenby 1982, Simenstad \& Cordell 1985, present study). There is some suggestion in the present study that $N$. mercedis at times obtained $P$. inopinus while foraging near the bottom, because $P$. inopinus often occurred in mysid diets along with benthic harpacticoid copepods and Corophium spp. amphipods.

Pseudodiaptomus inopinus may be an important new food source for Neomysis mercedis in the Chehalis River estuary. It often dominated the mysid diets during times when the $N$. mercedis population had high proportions of gravid females. It also had a high frequency of occurrence in $N$. mercedis diets during the late summer/early autumn period when the mysids produce generations that overwinter as large adults (Figs. 9 to 11; Johnston \& Northcote 1989). Additional questions remain as to the food web interactions of $N$. mercedis, $P$. inopinus, Crangon franciscorum and other abundant taxa. For example, $P$. inopinus undergoes diel vertical migration in the Chehalis River estuary (Bollens et al. 2002) and it is not known whether $N$. mercedis preys on $P$. inopinus mainly on the bottom during the day or if predation also occurs at night in the water column. Our finding of generally higher percentages of adult males in $N$. mercedis diets as compared to $C$. franciscorum diets may be indicative of feeding on more planktonic individuals of $P$. inopinus by $N$. mercedis, because there are numerous examples of male copepods occurring higher in the water column than females (see literature review by Schabetsberger \& Jersabek 2004).
Other questions concerning the food web are important but were not addressed in this study. First, we do not know if Pseudodiaptomus inopinus contributes to the diet of pelagic fish in the estuary because all of our fish samples were taken with a beach seine. Use of water column nets such as trawls and purse seines would provide more pelagic-oriented fish for diet analyses. Second, while $P$. inopinus appears to be important in the diets of Neomysis mercedis and Crangon franciscorum in the Chehalis River estuary, the extent to which it supplies the metabolic and nutritional needs of these predators in relation to native prey taxa is unknown. This could be addressed by the following studies: (1) feeding experiments using $P$. inopinus and native prey species to establish feeding response curves for different prey under different environmental conditions; (2) bioenergetic modelling, which would require measurements of consumption rates of the predators, energy content of the copepods and other prey taxa, and respiration and egestion of the predators (e.g. see Rudstam 1989); (3) establishing the fatty acid profile of $P$. inopinus to better understand its nutritional value to higher trophic levels - fatty acid profiles have only been established for a few calanoid copepods, and they can differ greatly based on copepod species and diets of the copepods themselves (Williams \& Biesiot 2004). Third, studies of the food sources for $P$. inopinus (e.g. using stable carbon isotope analyses; Hanson \& Tranvik 2003) would help to understand how this species is changing trophic pathways in its invaded habitats.

Although populations of Pseudodiaptomus inopinus have existed for more than $10 \mathrm{yr}$ in the Chehalis River and other northeast Pacific estuaries (Cordell \& Morrison 1996, J. R. Cordell, unpubl. data from 2000 \& 2004) its long-term fate there remains to be seen. In other estuaries, introduced copepods that appeared to have been well established have apparently been displaced by new copepod invasions. For instance, in the San Francisco estuary, the previously abundant Asian cyclopoid Limnoithona sinensis disappeared after the introduction of its congener L. tetraspina (Orsi \& Ohtsuka 1999). Likewise, in the Columbia River estuary and its tributaries, $P$. inopinus is now rare and has been replaced by 2 other Asian species, P. forbesi and Sinocalanus doerrii (Sytsma et al. 2004). S. doerri also occurs in the Chehalis River estuary, but is not yet abundant there in comparison to $P$. inopinus (J. R. Cordell pers. obs.). In addition, new introductions of predators may affect populations of both native and introduced estuarine copepods. For example, several species of Asian mysids and the predatory copepod Tortanus dextrilobatus have recently been introduced to the San Francisco estuary (Modlin \& Orsi 1997, Orsi \& Ohstuka 1999). Tortanus dextrilobatus has become 
very abundant and appears capable of significantly affecting its copepod prey (Bollens et al. 2002, Hooff \& Bollens 2004). Therefore, it appears that planktonic invasions in northeast Pacific estuaries are ongoing, and in some estuaries are evolving. Estuaries where most of these invasions occur are ecologically and hydrologically complex. Intensive long-term withinestuary studies and periodic broad-scale surveys of plankton assemblages in estuaries from this region are rare, but this type of information, along with more process-oriented studies of population dynamics, are needed in order to understand the status and impacts of invasive zooplankton species.

Acknowledgements. We especially thank W. Couch who shared responsibility for planning and conducting field sampling. J. Burke created maps and graphs of salinity distribution of sampling stations. B. Bachman, M. Haas, and J. Toft helped with sample collections. L. Tear conducted statistical analyses. Sampling for distribution of copepods across the full salinity gradient was conducted as part of a senior project by M.R. with the advice and help of B. Frost. O. Kalata and M. Koehler helped with sample enumerations and data entry, respectively. B. Frost and J. Pierson supplied helpful comments on the manuscript. This research was sponsored by Washington State Sea Grant, Project No. R/ES-30.

\section{LITERATURE CITED}

Ambler JW, Cloern JE, Hutchinson A (1985) Seasonal cycles of zooplankton from San Francisco Bay. Hydrobiologia 129:177-197

Bilio M, Niermann U (2004) Is the comb jelly really to blame for it all? Mnemiopsis leidyi and the ecological concerns about the Caspian Sea. Mar Ecol Prog Ser 269: 173-183

Benoit HP, Johannsson OE, Warner DM, Sprules WG, Rudstam LG (2002) Assessing the impact of a recent predatory invader: the population dynamics, vertical distribution, and potential prey of Cercopagis pengoi in Lake Ontario. Limnol Oceanogr 47(3):626-635

Bollens SM, Cordell JR, Avent S, Hooff R (2002) Occurrences, causes and consequences of zooplankton invasions: a brief review, plus two case studies from the northeast Pacific Ocean. Hydrobiologia 480:87-110

Boudreau SA, Yan ND (2003) The differing crustacean zooplankton communities of Canadian Shield lakes with and without the nonindigenous zooplanktivore Bythotrephes longimanus. Can J Fish Aquat Sci 60:1307-1313

Chigbu P (2004) Assessment of the potential impact of the mysid shrimp, Neomysis mercedis, on Daphnia. J Plankton Res 26:295-306

Chigbu P, Sibley TH, Beauchamp DA (1998) Abundance and distribution of Neomysis mercedis and a major predator, longfin smelt (Spirinchus thaleichthys) in Lake Washington. Hydrobiologia 386:167-182

Cooper KL, Hyatt KD, Rankin DP (1992) Life-history and production of Neomysis mercedis in British Columbia coastal lakes. Hydrobiologia 230:9-30

Cordell JR, Morrison SM (1996) The invasive Asian copepod Pseudodiaptomus inopinus in Oregon, Washington, and British Columbia estuaries. Estuaries 19:629-638
Cordell JR, Morgan CA, Simenstad CA (1992) Occurrence of the Asian calanoid copepod Pseudodiaptomus inopinus in the zooplankton of the Columbia River estuary. J Crust Biol 12:260-269

David V, Sautor B, Chardy P, Leconte M (2005) Long-term changes of the zooplankton variability in a turbid environment: the Gironde estuary (France). Estuar Coast Shelf Sci 64:171-184

Dzialowski AR, O'Brien WJ, Swaffar SM (2000) Range expansion and potential dispersal mechanisms of the exotic cladoceran Daphnia lumholtzi. J Plankton Res 22: 2205-2223

Feyrer F, Herbold B, Matern SA, Moyle PB (2003) Dietary shifts in a stressed fish assemblage: consequences of a bivalve invasion in the San Francisco estuary. Environ Biol Fish 67:277-288

Hanson LA, Tranvik LJ (2003) Food webs in sub-Antarctic lakes: a stable isotope approach. Polar Biol 26:783-788

Hooff RC, Bollens SM (2004) Functional response and potential predatory impact of Tortanus dextrilobatus, a carnivorous copepod recently introduced to the San Francisco Estuary. Mar Ecol Prog Ser 277:167-179

Hyatt KD, Ramcharan CR, McQueen DJ, Cooper KL (2005) Trophic triangles and competition among vertebrate (OnCorhynchus nerka, Gasterosteus aculeatus) and macroinvertebrate (Neomysis mercedis) planktivores in Muriel Lake, British Columbia, Canada. Ecoscience 12:11-26

Islam MS, Ueda H, Tanaka M (2005) Spatial distribution and trophic ecology of dominant copepods associated with turbidity maximum along the salinity gradient in a highly embayed estuarine system in Ariake Sea, Japan. J Exp Mar Biol Ecol 316:101-115

Johnston NT, Lasenby DC (1982) Diet and feeding of Neomysis mercedis Holmes (Crustacea, Mysidacea) from the Fraser River Estuary, British Columbia. Can J Zool 60: 813-824

Johnston NT, Northcote TG (1989) Life-history variation in Neomysis mercedis Holmes (Crustacea, Mysidacea) in the Fraser River Estuary, British Columbia. Can J Zool 67: 363-372

Kideys AE (2002) Fall and rise of the Black Sea ecosystem. Science 297:1482-1483

Kimmerer WJ, Gartside E, Orsi JJ (1994) Predation by an introduced clam as the likely cause of substantial declines in zooplankton of San Francisco Bay. Mar Ecol Prog Ser 113:81-93

Kimmerer WJ, Burau JR, Bennett WA (1998) Tidally oriented vertical migration and position maintenance of zooplankton in a temperate estuary. Limnol Oceanogr 43:1697-1709

Koepcke B (2004) The importance of peripheral areas and mudflats for the maintenance of Eurytemora affinis (Poppe, 1880) (Copepoda; Crustacea) populations in the Elbe Estuary. Arch Hydrobiol Suppl 110:330-343

Lawrence D, Valiela I, Tomasky G (2004) Estuarine calanoid copepod abundance in relation to season, salinity, and land-derived nitrogen loading, Waquoit Bay, MA. Estuar Coast Shelf Sci 61:547-557

Lee CE (2000) Global phylogeography of a cryptic copepod species complex and reproductive isolation between genetically proximate 'populations'. Evolution 54(6):2014-2027

Lee CE, Frost BW (2002) Morphological stasis in the Eurytemora affinis species complex (Copepoda: Temoridae). Hydrobiologia 480(1-3):111-128

MacIsaac HJ, Ketelaars HAM, Grigorovich IA, Ramcharan CW, Yan ND (2000) Modeling Bythotrephes longimanus invasions in the Great Lakes basin based on its European distribution. Arch Hydrobiol 149:1-21 
Mashiko K (1951) Studies on the fresh-water plankton of Central China, I. Science Reports Kwanazawa University 1:17-31

Modlin RF, Orsi JJ (1997) Acanthomysis bowmani, a new species, and A. aspera Ii, Mysidacea newly reported from the Sacramento-San Joaquin Estuary, California (Crustacea: Mysidae). Proc Biol Soc Washington 110:439-446

Morgan CA, Cordell JR, Simenstad CA (1997) Sink or swim? Copepod population maintenance in the Columbia River estuarine turbidity maxima region. Mar Biol 129:309-317

Nobriga ML (2002) Larval delta smelt diet composition and feeding incidence: environmental and ontogenetic influences. Calif Fish Game 88:149-164

Oka SI, Saisho T, Hirota R (1991) Pseudodiaptomus (Crustacea, Copepoda) in the brackish waters of mangrove regions in the Nansei Islands, southwestern Japan. Bull Biogeogr Soc Japan 46(8):83-87

Orsi JJ (1995) Radical changes in the estuary's zooplankton caused by introductions from ballast water. Interagency Ecological Studies Program for the Sacramento-San Joaquin Estuary, Newsletter, Summer 1995, p 16-17

Orsi JJ, Ohtsuka S (1999) Introduction of the Asian copepods Acartiella sinensis, Tortanus dextrilobatus, (Copepoda: Calanoida), and Limnoithona tetraspina (Copepoda: Cyclopoida) to the San Francisco Estuary, California, USA. Plankton Biol Ecol 46(2):128-131

Park OH, Suh HL, Soh HY (2005) Seasonal variation in the abundance of the demersal copepod Pseudodiaptomus sp. (Calanoida, Pseudodiaptomidae) in the Seomjin river estuary, southern Korea. Korean J Environ Biol 23(4):367-373

Rudstam LG (1989) Bioenergetic model for Mysis growth and consumption applied to a Baltic population of Mysis mixta. J Plankton Ecol 11(5):971-983

Schabetsberger R, Jersabek CD (2004) Shallow males, deep females: sex-biased differences in habitat distribution of the freshwater calanoid copepod Arctodiaptomus alpinus. Ecography 27:506-520

Shen C, Song D (1979) Calanoida. In: Shen C (ed) Fauna Sinica, Crustacea, Freshwater Copepoda. Science Press, Peking, p 53-163

Shen C, Tai AY (1962) The Copepoda of the Wu-Li Lake, Wu-Sih, Kiangsu Province I. Calanoida. Acta Zool Sin 14(1):99-118

Editorial responsibility: Robert Feller (Contributing Editor), Columbia, South Carolina, USA
Shiganova TA, Bulganova YV (2000) Effects of gelatinous plankton on Black Sea and Sea of Azov fish and their food resources. ICES J Mar Sci 57:641-648

Siegfried CA (1982) Trophic relations of Crangon franciscorum and Palaemon macrodactylus: predation on the opossum shrimp, Neomysis mercedis. Hydrobiologia 89:129-139

Simenstad CA, Cordell JR (1985) Structural dynamics of epibenthic zooplankton in the Columbia River delta. Verh Internat Verein Limnol 22:2173-2182

Simenstad CA, Eggers DM (eds) (1981) Juvenile salmonid and baitfish distribution, abundance, and prey resources in selected areas of Grays Harbor, Washington. FRI-UW8116, University of Washington School of Aquatic and Fishery Sciences, Seattle, WA

Suh HL, Soh HY, Cha SS (1991) Salinity and distribution of zooplankton in the estuarine system of Mankyong river and Dongjin river. J Oceanol Soc Korea 26:181-192

Sytsma MD, Cordell JR, Chapman JW, Draheim RC (2004) Lower Columbia River aquatic nonindigenous species survey 2001-2004. Final Technical Report: Appendices. Prepared for the United States Coast Guard and the United States Fish and Wildlife Service, 164 p. Available at: www.clr.pdx.edu/projects/columbia_river/lcrans/\#reports

Therriault TW, Grigorovich IA, Kane DD, Haas EM, Culver DA, MacIsaac HJ (2002) Range expansion of the exotic zooplankter Cercopagis pengoi (Ostroumov) into western Lake Erie and Muskegon Lake. J Great Lakes Res 28(4): 698-701

Ueda H, Terao A, Tanaka M, Hibino M, Islam MS (2004) How can river-estuarine planktonic copepods survive river floods? Ecol Res 19:625-632

Wahle RA (1985) The feeding ecology of Crangon franciscorum and Crangon nigricauda in San Francisco Bay, California. J Crust Biol 5:311-326

Williams JL, Biesiot PM (2004) Lipids and fatty acids of the benthic marine harpacticoid copepod Heteropsyllus nunni Coull during diapause: a contrast to pelagic copepods. Mar Biol 144(2):335-344

Yan ND, Pawson TW (1997) Changes in the crustacean zooplankton community of Harp Lake, Canada, following invasion by Bythotrephes cederstroemi. Freshw Biol 137: 101-117

Submitted: January 6, 2006; Accepted: July 17, 2006

Proofs received from author(s): February 26, 2007 